\title{
Self Disclosure Generasi Milenial melalui Second Account Instagram
}

\author{
Edy Prihantoro ${ }^{1}$, Karin Paula Iasha Damintana ${ }^{2}$, Noviawan Rasyid Ohorella ${ }^{3}$ \\ ${ }_{1,3}$ Magister Ilmu Komunikasi, ${ }^{2}$ Fakultas Ilmu Komunikasi, Universitas Gunadarma \\ Jl Margonda Raya No. 100, Depok, Indonesia \\ Email: edipri@staff.gunadarma.ac.id'; paulakarin17@gmail.com²; noviawanrasyid@gmail.com³* \\ *Corresponding author
}

\begin{abstract}
Millennials who were born together with technology are not far from technology, including the internet and social media today, namely Instagram. The purpose of this study is to find self-disclosure with freedom of expression and to eliminate the sense of insecurity felt by the millennial generation on the second Instagram account. The method used by researchers is a qualitative descriptive method in which the researcher observes, interviews, and documents several randomly selected informants starting from the age of 20 to 24 years (early adulthood). The theory used is the self-disclosure theory of Joseph Luft and Hary Ingham and the social constructivism paradigm. The results of the study explained that the averagemillennial generation has different levels of openness because every human being has different personalities. The second account is free to express and share what they want to share. The second account can help you to be more confident to appear bigger on the first account and eliminate the feeling of insecurity. Communication is more intimate on the second account because the account is locked and followers are only those closest to them. The substance of this research contributes in the form of new policy recommendations for all millennial generations to always be confident and be themselves. Keywords: Millennial Generation; Phenomenological; Self Disclosure
\end{abstract}

\begin{abstract}
Abstrak
Generasi milenial yang lahir bersamaan dengan teknologi membuat tidak jauh dengan teknologi, antara lain internet dan media sosial saat ini, yaitu Instagram. Tujuan dari penelitian ini untuk menemukan keterbukaan diri atau self disclosure dengan kebebasan berekspresi dan menghilangkan rasa insecure yang dirasakan oleh generasi milenial di second account Instagram. Metode yang digunakan oleh peneliti adalah metode deskriptif kualitatif dimana peneliti melakukan observasi, wawancara, dan dokumentasi terhadap beberapa informan yang dipilih secara acak berawal dari usia 20 sampai 24 tahun (dewasa awal). Teori yang digunakan adalah teori selfdisclosure dari Joseph Luft dan Hary Ingham, dan paradigma konstruktivisme sosial. Hasil penelitianmenjelaskan rata-rata generasi milenial memiliki tingkat keterbukaan yang berbeda-beda karena setiap manusia memiliki kepribadian yang tidak sama persis. Di second account bebas berekspresi dan membagikan apa yang mereka ingin bagikan. Second account dapat membantu diri untuk lebih percaya diri tampil lebih besar difirst account dan menghilangkan rasa insecure. Komunikasi yang dilakukan lebih intim di second account karena akun tersebut dikunci dan pengikutnya hanya orang-orang terdekat saja. Substansi penelitian ini memberikan kontribusi berupa rekomendasi kebijakan baru kepada seluruh generasi milenial untuk selalu percaya diri dan menjadi diri sendiri. Kata kunci: Generasi Milenial; Fenomenologis; Self Disclosure
\end{abstract}

\section{Pendahuluan}

Pengungkapan diri atau self disclosure adalah kemampuan orang dalam memberikan reaksi, tanggapan, atau informasi tentang dirinya yang biasanya di sembunyikan atau situasi yang sedang dihadapi untuk mencapai hubungan yang lebih jauh. Seseorang yang memiliki pengungkapan diri yang baik akan lebih memahami secara mendalam perilakunya. Self disclosure biasanya dilakukan kepada orang yang dipercainya. Seseorang melakukan pengungkapan diri kepada orang lain yang mendukungnya, namun tidak menutup kemungkinan orang lain yang bersangkutan menolak pengungkapan dirinya (Ignatius \& Kokkonen, 2007). Cangara (2016:165) menyatakan suatu upaya untuk memahami diri sendiri terkait dengan sebuah konsep yang dikenal dengan nama "Johari Window" atau Jendela Johari, sebuah kaca jendela yang terdiri dari empat bagian dimana keempat wilayah didalamnya merupakan satu kesatuan yang terdapat pada diri setiap orang. Terdapat wilayah terbuka (open area), buta (blind area), tersembunyi (hidden 
atau avoid area), dan tidak dikenal (unknown area). Teori ini digagas oleh dua psikolog Amerika, yaitu Joseph Luft dan Harrington Ingham pada 1955. Teori Jendela Johari juga berkaitan dengan Emotional Intelligence Theory dan kesadaran individu serta peningkatan EQ yang berhubungan dengan kesadaran dan perasaan manusia. Johari merupakan singkatan dari "Jo" berarti Joseph dan "Hari" berarti Harrington. Konsep teori ini memiliki empat perspektif yang masing-masing memiliki istilah berbeda dimana setiap makna mengandung pemahaman-pemahaman yang mempengaruhi pandangan seseorang. Hal tersebut mengenai perasaan kesadaran dan perilaku yang dimiliki dapat dipahami oleh diri sendiri, orang lain, atau keduanya dapat memahaminya.

DeVito (2007), self disclosure adalah mengkomunikasikan informasi mengenai diri kita sendiri kepada orang lain. Pada kajian komunikasi interpersonal, self disclosure merupakan salah satu pendekatan yang paling penting. Self disclosure adalah mengungkapkan informasi tentang diri kita yang biasanya tidak diketahui oleh orang lain. Pengungkaan diri melibatkan informasi yang kita komunikasikan kepada orang lain secara bebas atau informasi yang biasanya kita sembunyikan, bisa jadi menjadi sebuah informasi baru atau menjelaskan perasaan seseorang (DeVito, 2007:106).

Second account di Instagram merupakan hal baru yang dilakukan oleh banyak orang. Mereka melakukannya karena memiliki tujuan tertentu dan rata-rata yang melakukan hal tersebut adalah wanita. Penyebabnya emosi wanita sangat berbeda-beda dan mereka terkadang tidak ingin menahan sendiri. Adanya second account bisa menghasilkan hal yang berbeda dari yang tidak kita duga. Banyak hal baru yang dikeluarkan oleh seseorang melalui akun sampingannya. Emosi dan pikiran yang dituangkan lebih bebas karena seseorang membatasi followers pada akun tersebut, serta pengikutnya adalah orang yang dipercayainnya. Sehingga seseorang berani menuangkan pikiran dan emosi karena mereka saling percaya, tetapi tidak dipungkiri jika hasil dari orang lain akan sama dengan apa yang diharapkan oleh orang yang memiliki second account tersebut. Hal itu memunculkan bentuk dan dampak yang terjadi akibat self disclosure yang dilakukan oleh seseorang pada second account mereka masing-masing.

Pada penelitian yang dilakukan oleh Emeraldien, Aulia, \& Khelsea (2019) mengenai Instagram di UPN, Jawa Timur, bahwa mahasiswa Sani yang memiliki Finstagram disebabkan adanya ketidakamanan atau kurang percaya diri saat menggunakan akun utama mereka. Para informan mengaku tidak berani memposting apa yang ada di akun Finstagram ke akun Instagram utama mereka. Sebab, itu rawan mengubah citra diri dan bisa mengundang banyak cemoohan. Penelitian lain tentang penggunaan second account Instagram juga telah dilakukan oleh beberapa peneliti Dewi \& Janitra (2018); dan Kamilah \& Lestari (2020). Beberapa peneliti juga sudah melakukan penelitian terkait penggunaan Instagram bagi pengguna remaja yang merupakan bagian dari generasi milenial oleh Sakti \& Yulianto (2018); Mahendra (2017); Prihatiningsih (2017); Setiasih \& Puspitasari (2015); dan Putra (2019).

Pada penelitian lainnya yang dilakukan oleh Indriyani (2017) mengenai "Pengungkapan Diri Siswa di Media Sosial Instagram" bahwa tingkat keterubukaan diri di Instagram sebanyak 83,43\% siswa XI SMA negeri Kuningan memiliki pengungkapan diri yang tinggi atau negatif. Hal itu menyebabkan bahwa media sosial seperti Instagram bisa mengakibatkan dampak buruk bagi diri sendiri dan orang lain jika dilakukan tanpa adanya batasan dalam melakukan keterbukaan diri di Instagram. Penelitian lain tentang self disclosure sudah dilakukan dan dipublikasikan oleh Sagiyanto, \& Ardiyanti (2018); Mahardika \& Farida (2019); Setiadi (2019); Miranda (2019); Fauzia, Maslihah, \& Ihsan (2019); dan Johana, Lestari, \& Fauziah (2020) Menggunakan teori Johari Window, peneliti melakukan penelitian terhadap generasi milenial dengan Johari Window, sehingga narasumber terlihat masuk ke dalam bagian jendela satu, dua, tiga, atau empat yang menghasilkan karakteristik dari pengguna dalam menggunakan 
second account Instagram. Ketertarikan penulisan dalam melakukan penelitian ini adalah ingin melihat bentuk dan dampak yang dihasilkan si pengguna dalam menggunakan Instagram dan masuk ke dalam bagian atau tipe apa di dalam teori Johari Window.

\section{Metode Penelitian}

Objek penelitian ini adalah self disclosure dan subjeknya terdiri dari enam informan yaitu generasi milenial berusia 20-24 tahun. Penelitian ini bersifat kualitatif dengan pendekatan deskriptif yang bertujuan unttk mendeskripsikan atau menggambarkan secara sistematis faktual dan akurat mengenai faktor-faktor sifat serta hubungan antara fenomena yang diteliti berupa kata-kata dan gambar bukan dengan angka-angka.

Metodologi kualitatif adalah prosedur penelitian yang menghasilkan data deskriptif berupa kata-kata tertulis atau lisan dari orangorang dan perilaku yang diamati. Pendekatan ini diarahkan pada latar dan individu tersebut secara holistik (utuh). Jadi tidak boleh mengisolasikan individu atau organisasi ke dalam variabel atau hipotesis, tetapi perlu memandangnya sebagai bagian dari suatu keutuhan (Moleong, 2005).

Paradigma adalah bentuk suatu cara pandang untuk memahami kompleksitas dunia nyata. Paradigma bersifat normatif, yang menunjukan kepada praktisinya apa yang harus dilakukan tanpa perlu melakukan pertimbangan. Paradigma adalah kumpulan longgar dari sejumlah asumsi yang dipegang bersama, konsep, atau proposisi yang mengarahkan cara berfikir dan penelitifn atau sebagai cara mendasar untuk mempresepsi, menilai dan melakukan yang berkaitan dengan sesuatu secara khusus tentang visi realitas (Moleong, 2005).

Penelitian ini menggunakan pendekatan kualitatif dengan jenis penelitian fenomenologis. Pendeketan fenomenologis adalah pendekatan yang diperoleh dengan memperhatikan fenomena yang terjadi. Fenomena tersebut adalah fenomena yang terjadi pada generasi milenial yang berhubungan dengan penggunaan second account di Instagram dan melihat apa saja fungsi Instagram sebagai media self disclosure generasi milenial.
Penelitian ini menggunakan metode observasi. Observasi merupakan kegiatan pengamatan secara inderawi yang direncanakan, sistematis dan hasilnya dicatat serta diinterpretasikan dalam rangka memperoleh pemahaman tentang objek yang diamati.

Pada penelitian deskriptif kualitatif maka pengambilan data tersebut menggunakan beberapa teknik, yaitu: 1) Interview (wawancara) merupakan percakapan dengan maksud tertentu yangdilakukanolehkeduabelahpihak, yaituantara pewawancara dengan mengajukan beberapa pertanyaan kepada individu sebagai narasumber yang bersangkutan. Peneliti melakukan tanya jawab secara langsung dengan orang-orang yang memiliki second account di Instagram; 2) Dokumentasi merupakan teknik pengumpulan data melalui pengumpulan dokumen-dokumen untuk memperkuat informasi; 3) Observasi merupakan sebuah teknik pengumpulan data yang dilaksanakan dengan cara mempelajari dan mengadakan pengamatan secara langsung kedalam sebuah perusahaan untuk mendapatkan bukti-bukti yang dapat mendukung dan melengkapi hasil penelitian. Peneliti melakukan observasi di rumah melalui teknologi informasi dan komunikasi, yaitu media sosial.

Peneliti menggunakan teknik analisis data kualitiatif milik Miles dan Huberman. Kegiatan analisis terdiri dari tiga alur kegiatan yang terjadi secara bersamaan, yaitu reduksi data, penyajian data, dan penarikan kesimpulan atau verifikasi. Terjadi secara bersamaan sebagai sesuatu yang saling jalin menjalin merupakan proses siklus dan interaksi pada saat sebelum, selama, dan sesudah pengumpulan data dalam bentuk sejajar yang membangun wawasan umum yang disebut "analisis". Berikut adalah teknik analisis data yang digunakan oleh peneliti, yaitu: 1) Reduksi Data merupakan kegiatan merangkum, memilih hal-hal yang pokok, memfokuskan pada halhal penting. Catatan-catatan lapangan dengan memilih hal-hal pokok yang berhubungan dengan nilai-nilai peran dan fungsi kepala sekolah dalam meningkatkan mutu yang diterapkan. Rangkuman catatan-catatan lapangan itu kemudian disusun secara sistematis agar memberikan gambaran 
yang lebih tajam serta mempermudah pelacakan kembali apabila sewaktu-waktu data diperlukan kembali; 2) Display Data dilakukan setelah data direduksi. Langkah ini berguna untuk melihat gambaran secara keseluruhan hasil penelitian, baik yang berbentuk matrik atau pengkodean. Kemudian dari hasil reduksi data dan display data itulah selanjutnya peneliti dapat menarik suatu kesimpulan dan memverifikasi sehingga menjadi kebermaknaan data; 3) Kesimpulan dan Verifikasi dilakukan untuk menetapkan kesimpulan yang coba-coba, apakah sepanjang penelitian berlangsung sejalan dengan member check, triangulasi dan audit trail, sehingga menjamin signifikasi atau kebermaknaan hasil penelitian. Setelah verifikasi selesai maka dilakukan pembahasan hasil temuan di lapangan. Hasil temuan di lapangan disesuaikan dengan teori yang ada untuk mendapat kesesuian dan mendapatkan kesimpulan.

\section{Hasil Penelitian dan Pembahasan}

Generasi milenial di era digital saat ini sangat dipengaruhi oleh gaya modernisasi. Milenial sering menjadi topik perbincangan di kalangan masyarakat dari segi pendidikan, teknologi, politik, moral, budaya, dan gaya hidup. Generasi milenial adalah generasi yang sangat melek teknologi, sehingga pekerjaan kesehariannya tidak pernah jauh dari kecanggihan. Adanya perkembangan teknologi mendukung generasi ini yang sifatnya menyukai aktivitas yang serba cepat dan instan. Adaptasi terhadap teknologi dan kemampuan yang lebih tinggi dibanding dengan generasi sebelumnya juga dapat dibuktikan dengan tingginya persentase pengguna teknologi informasi seperti telepon seluler, komputer, dan internet.

Self disclosure atau pengungkapan diri bagi generasimilenialmerupakan salahsatu caraefektif dalam usaha untuk eksistensi diri, menemukan identitas diri dan sebagai sarana komunikasi dan informasi untuk sesama. Eksistensi diri maupun menemukan jati diri akan memudahkan mereka dalam membentuk konsep diri yang tepat.
Begitu pula dengan informan-informan peneliti yang semuanya menggunakan second account di Instagram sebagai upaya untuk melakukan self disclosure di media sosial dan kepada orang lain (Bazarova \& Choi, 2014; Trepte, 2015). Hal itu akan memudahkan keduanya untuk menilai kekurangan dan kelebihan yang dimiliki seseorang tersebut serta dapat mengembangkan diri dikarenakan rasa nyaman dalam melakukan keterbukaan di second account. Meskipun demikian, terdapat modelmodel tertentu bagi mereka agar pengungkapan diri yang mereka lakukan tidak merugikan bagi diri mereka sendiri dan orang lain.

Pada second account, informan tidak hanya menunjukan kegiatan sehari-hari atau informasi yang umum saja, perihal kesedihan, kekecewaan, keseruan, dan membagikan banyak hal ke dalam media sosial Instagram tersebut. Hal tersebut sesuai dengan apa yang peneliti temukan selama wawancara maupun observasi. Bagi Yudia, melakukan keterbukaan diri di second account itu lebih bebas, seperti penuturannya sebagai berikut:

"Kalau di second account gaada batasannya seperti apa, jadi saya bisa bebas. Lebih ke yang saya mau, ga harus saya ekspresiin dengan saya suka nari kayak gitu tapi saya suka kayak posting hal yang berbau makanan, jalan-jalan, atau kayak favorit saya kopi gitu aja sih cuman engga kayak khusus saya harus joget-joget nyanyi kayak gitu. Iya menurut saya kayak aib atau memes temen maupun sendiri juga jadi salah satu ekspresi orang lain kalau misalkan oh ini juga bisa buat mereka ketawa gitu" (Yudia, 2020). Menurut Yudia, second account merupakan tempat yang bisa membuat dia lebih bebas dalam mengekspresikan apa yang dia mau. Dia juga merasa selain mengeskpresikan diri dia lebih bebas, dia juga merasa dengan membagikan sesuuatu yang lucu dan bagus bisa membuat orang lain senang. Yudia juga beranggapan bahwa posting di first account berbeda dengan apa yang dia rasakan saat posting di second account, penuturannya sebagai berikut: 
"Kalau di first account beberapa waktu yang lalu, saya juga banyak postingan yang cukup komersil, jadi kalau foto juga harus sesuai dengan syarat dan ketentuannya dari brand tersebut. Mungkin kalau di first account itu lebih kayak orang-orang yang umum, general aja yang mungkin kita kenal. saya lebih dominan setiap harinya itu dominan buka akun ke second account saya selain saya juga follow online shopping atau artis-artis yang saya idol lain, udah gitu juga banyak teman-teman dekat saya yang ada di second account, saya juga suka posting keseharian saya disitu. kalo di first account kan jarang" (Yudia, 2020).

Begitu juga dengan informan lainnya yaitu Naurah. Dirinya melakukan keterbukaan dirinya dengan cara yang berbeda di second account. Biasanya orang lain terbuka dengan membagikan kehidupan sehari-hari tetapi Naurah lebih ke arah apa yang dia suka. Naurah terbuka dengan apa yang dia suka dan hanya sebatas itu. Penuturannya sebagi berikut: "Tujuannya untuk cuma pengen ngefollow artis/idol pengen liat di timeline tanpa terganggu foto-foto temen yang lain. pengen bikin ini juga aesthetic instagram, jadi kalau scroll ig saya isinya ada yang aesthetic, ungu, ijo, merah bener-bener kayak nine grid, 9 foto dengan isi yang warnanya sama, makanya isinya nyampah banget, maka itu sih gunanya instagram yang ini untuk nyampah" (Naurah, 2020). Informan selanjutnya yaitu Salma. Dirinya masih sering membuka kedua akunnya tersebut tetapi dia juga lebih terbuka di second account dikarenakan tujuan dia membuat akun tersebut karena dia ingin spam dan terbuka dengan bebas. Penuturannya sebagai berikut: "Jadi awal mula saya membuat second account itu, ketika saya merasa gabut dan saya juga ingin update story dan feeds instagram yang aneh-aneh, yang lucu-lucu aja gitu. yang ga formal-formal banget. sih biasanya membagikan video yang gila dan aneh gitu ya dari sisi saya sendiri terus saya membagikan quotes-quotes juga gitu untuk menyamangati diri saya dan temanteman saya yang membaca, saya juga bikin video-video tiktok. soalnya setelah saya update story di second itu saya merasa lebih senang, terus lebih sedikit tambah percaya diri juga dan saya juga ikut seneng gitu melihat temen-temen saya yang terhibur jadi saya seneng juga buat bikin konten-konten selanjutnya" (Salma, 2020)

Ada hal lain juga yaitu bahwa Salma merasa first account itu sedikit berbeda dengan second account, karena Salma sudah terbiasa mengekspresikan dirinya yang cukup lumayan besar ke publik sehingga dia merasa akun pertama dan kedua tidak beda begitu jauh. Perbedaan yang dimaksud adalah dia tidak terlalu merasa insecure dikarenakan apa yang orang share itu adalah hak mereka dan saya adalah saya. Penuturannya sebagai berikut:

"Kalau di first itu saya lebih memfilter ya story yang akan saya berikan kepada temen-temen tuh kayak gimana gitu, harus lebih sopan lebih formal terus yang agak-agak serius gitu. nah kalau di second itu saya lebih bebas membagikan story tentang apa saja yang saya sukai. Kedua akun sama-sama positif sih lingkupnya gaada yang negatif, bully segala macem gitu. Kalo insecure sih engga, karena ya itu hidup-hidup mereka, saya juga punya hidup sendiri, saya lebih fokus ke hidup saya sendiri aja gitu" (Salma, 2020).

Selanjutnya adalah Adinda. Adinda merasa bahwa dia lebih sering main di akun kedua untuk lebih kearah spamming karena jika di akun pertama dia merasa hal itu sedikit mengganggu. Penuturannya sebagai berikut:

"Karena lumayan sering juga ngepost di second account, sekedar buat apasih spamming di story aja sih sebenernya. Kalau buat scale one to ten kayaknya di tujuh lah ya. Biasanya kalau di second account selain posting jalan-jalan gitu, aku pribadi sering posting di story ya dari pada di post instagramnya. Paling kalau di story itu aku suka ngepost tentang aku lagi suka banget nonton ice hockey jadi suka ngeshare ice hockey di story atau sekedar repost postingan tertentu gitu ke story atau suka ngepost kucing-kucing juga, namanya nala, simba, cemong, gitu" (Adinda, 2020).

Informan lainnya yaitu Annisa. Menurutnya membuat second account itu penting karena dia masih tidak percaya diri untuk membagikan tentang dirinya maupun foto 
dirinya sendiri kedalam akun pertama. Ada beberapa foto dirinya tetapi tidak sesering yang dia bagikan di akun keduanya. Banyak hal yang dia rasakan setelah membuat akun kedua tersebut, penuturannya sebagi berikut: "Paling saya lebih gunain untuk mengupload hal-hal yang engga saya upload di first account saya sih. Jadi saya tuh lebih pede untuk upload-upload foto, video, snapgram itu di second account ini. Awalnya juga pengen ngerapihin feeds gitu jadinya id second account, pengen terlihat rapih gitu feedsnya dan ya rapih dan sampe sekarang ya lumayan lah, malah sekarang lebih rapih feeds instagram kedua saya dari pada yang pertama gitu. karena saya lebih pede, nyaman aja gitu upload apa aja, foto saya, foto pemandangan, foto selfie, foto aib temen-temen juga ada disitu, kayak kegiatankegiatan saya, pokoknya hal-hal yang engga saya pede untuk upload difirstaccount jadinya saya upload di second account sekalian caption-caption yang lebih mendalam gitu, lebih pribadi. Tujuannya juga kayak diri saya lebih terbuka aja gitu, pokoknya disitu saya ngeluarin semuanya deh yang engga saya keluarin di first account. Di second account juga saya suka curhat sih, meluapkan isi hati saya, apa kesukaan saya" (Annisa, 2020).

\section{Analisis Berdasarkan Penelitian}

Penelitian ini berkaitan dengan penelitian yang telah di lakukan sebelumnya oleh Sabaruddin (2019) yang berjudul self disclosure Pada Mahasiswa Politeknik Pertanian Negeri Pangkep. Menjelaskan mengenai self disclosure yang dilakukan oleh mahasiswa yang dimana dilakukan di media sosial instagram sebagai model aktualisasi diri. Mahasiswa mengungkapakan dirinya di daerah terbuka (public area) dimana keterbukaan seseorang akan membagikan identitas, informasi, perasaan, keinginan, gagasan serta aktivitas kampus secara terbuka karena mengharapkan feedback dari orang lain. Self disclosure tersebut memiliki fungsi dan bentuk yang bertujuan untuk melihat seberapa besar pengungkapan diri mahasiswa di Instagram. hal ini merupakan konsep yang sejalan antara peneltian ini dan penelitian milik Sabaruddin tersebut.
Perbedaan dari penelitian antara kedua penelitian ini yaitu dari segi subjek dan (platform) yang berbeda. Penulis memiliki referensi dari Emeraldien, Aulia, \& Khelsea (2019). untuk platform yang digunakan yaitu Finstagram atau nama lainnya Fake Instagram. Dalam penelitiannya yang berjudul The Use of Finstagram as A Platform for Self-Disclosure tahun 2019. Penelitian tersebut menjelaskan bahwa mahasiswa UPN "Veteran" di Jawa Timur menggunakanFinstagramuntukmengeskpresikan keterbukaan dirinya, mahasiswa tersebut lebih terbuka dengan cara upload berbagai foto, video dan memberikan informasi pada Finstagram mereka. Akun Finstagram ini hanya bisa diikuti oleh teman-temannya yang sangat dekat sehingga orang yang memiliki akun tersebut bisa bebas dalam upload hal apapun. Peneliti juga sama dalam menggunakan fake Instagram dengan nama lain yaitu second account yang biasa dipakai oleh generasi milenial.

Selanjutnya, penelitian ini juga berkaitan dengan penelitian sebelumnya oleh Ningsih (2015) yang berjudul Self Disclosure Pada Media Sosial. Menjelaskan bahwa self disclosure pada media anonim menjadikan individu lebih nyaman terbuka mengenai dirinya. Dimensi atau aturan dalam pengungkapan diri yang terjadi oleh informan Lega Talk ini berkaitan dengan aspek frekuensi (tingkat keseringan) dan durasi (lama akses) yang dibutuhkan oleh informan untuk mengungkapkan diri tidak menentu dan tidak dapat diprediksi. Fungsi Self disclosure sebagai bentuk ekspresi. Fungsi tersebut merupakan perihal yang sama dengan penelitian saat ini.

Lalu penelitian ini juga berkaitan dengan penelitian sebelumnya oleh Suyadi \& Triyono (2017) yang berjudul Media Sosial dan Self Disclosure. Menjelaskan bahwa pengungkapan diri yang dilakukan wanita lebih tinggi dibandingkan dengan pria. Wanita lebih mudah mengungkapkan isi hatinya melalui media sosial, sedangkan prialebihseringmemberikan informasi dari pada mengungkapkan perasaan mereka. Hasil dari wanita lebih besar dalam pengungkapan diri di media sosial memiliki kesamaan dalam objek yang sedang peneliti lakukan saat ini. 
Tabel 1 Jendela Johari “Open Minded Person”

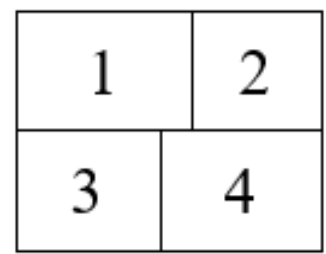

Sumber: Hasil Olahan Peneliti (2020)

Penelitian ini juga berkaitan dengan penelitian sebelumnya oleh Sagiyanto \& Ardiyanti (2018) yang berjudul Self Disclosure Melalui Media Sosial Instagram. Menjelaskan anggota Galeri Quote memanfaatkan media sosial Instagram untuk memenuhi kebutuhkan aktualisasi diri mereka. Hal ini sejalan dengan penelitian saat ini dimana generasi milenial membutuhkan aktualisasi diri di second account Instagram mereka.

Kelima penelitian ini dijadikan oleh penulis menjadi acuan untuk mengembangkan dan menggabungkan kedua penelitian yang sudah penulis baca yang menjadikan sebuah inovasi baru dalam dunia komunikasi.

Setelah melakukan analisa terhadap data yang diperoleh, peneliti menkonstruksikan antara data yang diperoleh di lapangan dengan teoriteori yang sudah ada. Pertanyaan di atas dibuat berdasarkan indikator atau elemen yang terdapat dalam teori self disclosure, dimana teori ini merupakan teori dari Joseph Luft dan Harrington Ingham yang bisa disebut teori Johari Window.

Teori Johari Window merupakan sebagai salah satu cara untuk melihat dinamika selfawareness yang berkaitan dengan perilaku, perasaan, dan motif manusia. Pada teori Johari terdapat empat bingkai dimana terdiri dari: Area terbuka, Area buta, Area tersembunyi, dan Area tidak diketahui atau tertutup.

Sesuai dengan area-area tersebut, maka informan Yudia setelah dianalisis sesuai dengan hasil dari wawancara dan observasi bahwa Yudia adalah masuk kedalam kategori "Open Minded Person" yaitu tipe manusia ideal. Kategori ini adalah manusia yang selalu terbuka dengan orang lain sehingga pengalaman dan interest menjadi lebih luas (open minded person). Bingkai nomor 1 sedikit bergeser menjadi diperbesar.
Tabel 2 Jendela Johari "Open Minded Person"

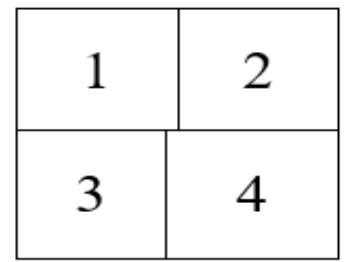

Sumber: Hasil Olahan Peneliti (2020)

Dari tabel 1, Yudia membuka area atau bingkai nomor 1 yaitu area terbuka (open area) menjadi bergeser lebih luas. Area terbuka yang dimaksud adalah dimana berisikan informasi, peilaku, sikap, perasaan, keinginan yang diketahui oleh diri kita dan orang lain. Yudia memiliki area tebuka yang lebih luas dan dirinya sendiri sadar akan apa yang dimiliki dan dia tahu bahwa orang lain mengetahui dirinya begitu baik.

Semua manusia tidak memiliki area yang sama besar dengan lainnya. Tentu setiap area selalu berbeda-beda dan Yudia memilliki area 1 yang lebih luas dan besar perbedaannya dibanding area 1, 3 dan 4. Hal itu terjadi karena seringnya Yudia membagikan kehidupan pribadinya yang begitu luas dan serignnya update yang dilakukan di second account bahkan untuk hal yang terlihat tidak wajar pun terkadang dia berani membagikannya karena dia tahu ini adalah akun dimana untuk membagikan apa yang dia suka dan bebas berekspresi. Seringnya jalan-jalan dan bertemu teman juga membuat Yudia termasuk orang yang terbuka, dia juga menerima masukan yang diberikan temantemannya saat dia bertanya di akunnya tersebut.

Informan Rini merupakan pribadi yang masuk kedalam kategori "Open Minded Person" dimana dalam kategori tersebut memiliki banyak informasi dan pengetahuan tentang dirinya dan orang lain. Bingkai atau area yang bergeser lebih luas adalah nomor 1, yaitu area terbuka atau daerah terbuka.

Open minded person adalah dimana area atau bingkai nomor 1 dibuka sehingga bergeser luas. Area nomor 1 ini bisa disebut area terbuka atau open area yang mengandung semua informasi yang diketahui diri sendiri dan orang lain 
Tabel 3 Jendela Johari "Type Interviewer"

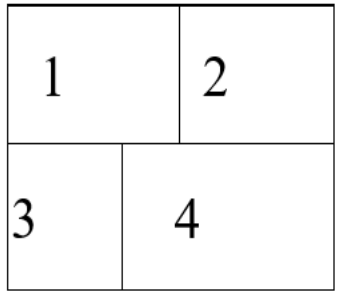

Sumber: Hasil Olahan Peneliti (2020)

mengetahuinya juga. Kategori ini disebut open minded person dimana pribadi sangat terbuka dengan segala hal dan informasi dirinya juga suka untuk diberikan kepada orang lain sehingga orang lain pun mengenal baik karakteristik Rini. Kategori Rini sama seperti informan Yudia, tetapi bingkai tersebut berbeda. Tidak semua bingkai memiliki luas yang sama. Pada keterbukaan diri atau self disclosure, bingkai Yudia lebih luas dibanding Rini karena Yudia lebih aktif dalam berkespresi dan bercerita. Jika Rini jarang melakukan itu, lebih sering ke hal berbagi atau sharing makanan maupun tips-tips untuk perempuan. Walaupun di first account Rini termasuk humble dan suka post kelucuan temantemannya tetapi hal tersebut hanya sebatas keseruan disuatu moment bukan kearah yang lebih terbuka begitu juga dengan second accountnya, yang jarang melakukan hal seperti itu tetapi dia cukup terbuka hanya saja tidak sesering Yudia.

Berdasarkan hasil wawancara dan observasi, Naurah memiliki kategori yang berbeda didalam teori Johari Window, dimana Naurah masuk kedalam kategori "Type Interviewer", yaitu pribadi yang tahu banyak orang lain tetapi dia menutup dirinya (type interviewer)

Di Type Interviewer bingkai yang bergeser lebih luas adalah nomor 4, yaitu Naurah dominan pada area tertutup (hidden area) dimana mengandung semua hal yang kita ketahui tentang diri sendiri dan tentang orang lain, tetapi hanya menyimpannya untuk diri kita sendiri. Ini adalah area dimana kita merahasiakan segala sesuatu tentang diri dan tentang orang lain. Area ini juga bisa termasuk area yang tidak dikenal yang merupakan wilayah yang paling kritis dalam komunikasi. Selain terkadang tidak mengenal
Tabel 4 Jendela Johari "Open Minded Person"

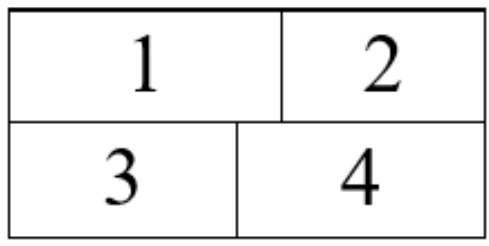

Sumber: Hasil Olahan Peneliti (2020)

diri sendiri dan orang lain tidak mengetahui siapa kita. Sehingga Naurah jarang update tentang dirinya, tidak terbuka dengan teman-teman dekatnya, dia hanya sebatas sharing apa yang dia suka, perihal kehidupannya sangat jarang sekali untuk dibagikan, walaupun sudah menggunakan second account tetapi untuk membagikannya Naurah tidak ingin melakukannya. Penyebabnya Naurah juga sedang struggling dengan dirinya sendiri. Hal tersebut pun tidak dia curahkan di second account. Naurah hanya ingin mendapat hiburan yang saat ini itu adalah K-Pop. Sehingga dia memilih hal yang dia suka untuk membantu dia semangat dalam menajalani kehidupannya.

Selanjutnya adalah Salma. Berdasarkan analisis melalui wawancara dan hasil observasi maka dia masuk kedalam kategori "Open Minded Person" yaitu tipe manusia ideal. Kategori ini adalah manusia yang selalu terbuka dengan orang lain sehingga pengalaman dan interest menjadi lebih luas (open minded person). Bingkai nomor 1 sedikit bergeser menjadi diperbesar.

Open minded person adalah area atau bingkai nomor 1 terbuka sehingga bergeser luas. Area nomor 1 ini bisa disebut area terbuka atau open area yang mengandung semua informasi yang diketahui diri sendiri dan orang lain mengetahuinya juga. Kategori ini disebut open minded person dimana pribadi sangat terbuka dengan segala hal dan informasi dirinya juga suka untuk diberikan kepada orang lain sehingga orang lain pun mengenal baik karakteristik Salma. Bingkai nomor 1 Salma tidak seluas Yudia tetapi lebih luas dibandingkan Rini karena seringnya update tentang kehidupan sehari-hari membuat Salma secara tidak sadar melakukan keterbukaan yang lebih luas. Hal-hal yang Salma bagikan juga 
Tabel 5 Jendela Johari "Loner and Loner and Turtle"

\begin{tabular}{|c|c|}
\hline 1 & \multicolumn{2}{|c|}{2} \\
\hline 3 & 4 \\
\hline
\end{tabular}

Sumber: Hasil Olahan Peneliti (2020)

berasal dari dirinya sendiri, seperti keanehan dan kelucuan yang dilakukannya membuat dirinya lebih bereskpresi dan aktif. Kehidupan sehari-harinya juga tidak jarang dibagikan oleh Salma. Selain hal seru dan kehidupan seharihari, dirinya jarang membagikan apa yang sedang dia rasakan, dia jarang mencurahkan isi perasaannya. Dia lebih fokus pada dirinya dan untuk update dia lebih baik membagikan hal lucu agar menghibur dirinya dan juga temannya. Sehingga banyaknya konten yang dia berikan guna menghibur dan have fun saja.

Adinda masuk kedalam kategori "Loner and Loner and Turtle" yaitu dimana pribadi yang suka menyendiri dan sifatnya seperti penyu, maka bingkai yang terbuka lebar adalah nomor 3 .

Area yang dominan adalah area tersembunyi atau unknown area karena kemampuan Adinda tidak banyak orang yang mengetahuinya, tetapi bingkai yang bergeser tidaklah sangat besar karena Adinda masih suka update di story. Adinda juga sering jalan ke luar negeri, tetapi itu semua dia lakukan sendiri. Adinda suka berpergian sendiri, dan aktivitas selain di kampus, dia hanya berada di kost atau dirumah. Adinda suka bermain dengan kucing dan menonton streaming pertandingan, games, dan film. Adinda juga menjadi pendengar untuk teman-temannya yang sedang curhat tetapi orangnya hanya sebatas itu-itu saja tidak lebih sehingga tidak banyak dan sering dilakukan komunikasi antar Adinda dan temannya di media sosial second account.

Selanjutnya adalah informan Annisa. Berdasarkan hasil wawancara dan observasi menunjukan bahwa Annisa masuk kedalam kategori "Exhibitionist". Kategori ini
Tabel 6 Jendela Johari "Exhibitionist"

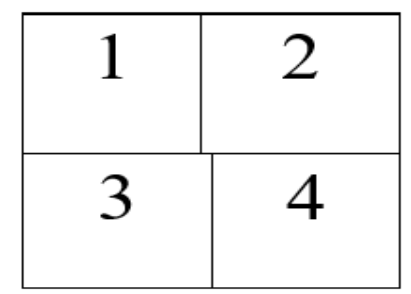

Sumber: Hasil Olahan Peneliti (2020)

adalah pribadi yang suka menunjukan atau menonjolkan dirinya, tetapi buta terhadap dirinya sendiri (exhibitionist or bull in chinashop). Bingkai nomor 2 diperbesar.

Bingkai nomor 2 bergeser menjadi lebih luas dibandingkan dengan bingkai laiinya. Maka area nomor 2 adalah area buta atau blind area dimana berisikan informasi tentang diri kita yang diketahui orang lain, tetapi kita sendiri tidak mengetahuinya. Annisa terlihat dari observasi selama seminggu di statusnya terlihat karakteristiknya yang tampaknya dia sendiri tidak menyadari berbagai kekeliruan yang dibuatnya.

Annisa sering update tentang kesehariannya begitu juga terkadang curhat walaupun tidak begitu sering. Namun terkadang Annisa merasa lost dan bingung dengan dirinya, dia sempat menanyakan ke orang-orang "saya itu seperti apa sih?" atau "saya seperti ini benar kan?" dan lainnya. Dia juga membagikan sesuatu di story lalu temannya berkata bahwa dia baper tetapi dia tidak yakin apakah dirinya seperti itu atau tidak. Walaupun Annisa masuk kedalam kategori tersebut, tidak berarti sepenuhnya Annisa buta dengan dirinya karena bingkai yang bergeser juga tidak begitu besar.

Menurut Jospeh Luft dan Harrington Ingham, empat area atau empat wilayah pada konsep Johari Window merupakan satu kesatuan yang terdapat dalam diri di setiap orang. Hanya saja, kadar wilayahnya itt sangat berbeda antara satu orang dengan yang lain. Seseorang yang ingin sukses di dalam lingkungan masyarakat sosiat, harus memperbesar area terbuka. Jika memperbesar area terbuka, tiga area lain akan mengecil. 
Teori ini terus berkembang seiring arus globalisasi yang mempengaruhi masyarakat dalam berkomunikasi dan semakin canggih juga teknologi internet or new media 2.0, sehingga saat ini generasi milenial tidak bisa lepas dengan internet begitu juga media komunikasi atau media sosial yang sudah menjadi kebutuhan utama mereka di era ini. Kemunculan dan berkembangnyateoriselfdisclosurekarenabanyak generasi milenial yang melakukan keterbukaan diri melalui internet, terutama media sosial.

Peneliti menggunakan teori self disclosure untuk mencoba memahami dan melihat seberapa nyaman dan percaya dirinya mereka untuk melakukan keterbukaan diri di second account dibandingkan dengan akun utamanya atau first account. Munculnya perasaan insecure juga karena kesuksean, kecantikan, dan keahlian orang lain yang menjadi salah satu dorongan juga untuk terbuka dan bertahan di second account. Mereka menganggap bahwa saat ini, akun utamanya hanya untuk sebatas simbol umum tentang dirinya dari hasil kemasan foto yang terbaik seperti layaknya galeri di museum.

Keterbukaan diri di media sosial harus dibatasi sehingga tidak membahayakan diri sendiri dan bisa saja mengganggu orang lain. Semua yang dilakukan memang seharusnya sewajarnya saja, semua pasti ada batasan. Batasan itu yang membuat kita tetap berada di jalur yang benar dan aman. Semakin besar arus globalisasi dan meningkatnya perubahan teknologi, membuat kita harus semakin belajar dan memahami apa yang boleh dilakukan dan tidak boleh dilakukan. Jangan terbawa arus, tetapi berusaha menyesuaikan arus tanpa harus merusak diri sendiri dan orang lain.

\section{Simpulan}

Hasil dari penelitian ini menyimpulkan bahwa melalui second account di Instagram, generasi milenial dapat mengungkapkan dirinya dengan efektif. Bagi para milenial informasi yang diberikan terkait dengan identitas diri dan perasaan serta keadaan yang mereka alami. Pada second account mereka lebih terbuka karena akun tersebut di private sehingga yang bisa melihat apa yang mereka bagikan hanyalah orangorang yang sangat dekat dan mereka percayai.
Adanya second account membuat mereka bisa menambah rasa percaya diri dalam memutuskan apa yang mereka harus bagikan ke banyak orang suatu saat nanti, sehingga apa yang mereka bagikan di first account hanyalah identitas yang sudah dikemas dan direncanakan sebaik mungkin agar orang umum atau general melihat mereka sesuai dengan apa yang mereka inginkan, tidak memperlihatkan sisi asli mereka itu sendiri. Sehingga akun utamanya atau first account hanyalah untuk sebagai simbol diri yang sudah dikemas dengan baik, dengan kata lain mendekati kesempurnaan dan keindahan untuk dilihat. Kategori yang terbentuk dari masingmasing informan dengan kategori dari Jendela Window itu sendiri sebagai berikut: 1) Yudia, Rini dan Salma merupakan pribadi yang terbuka dan masuk kedalam kategori "Open Minded Person"; 2) Naurah merupakan pribadi yang mengetahui tentang dirinya dan tentang orang lain dan masuk kedalam kategori "Type Interviewer"; 3) Adinda merupakan pribadi yang tertutup dan masuk kedalam kategori "Loner and Loner and Turtle"; 4) Annisa merupakan pribadi yang tidak mengetahui dirinya tetapi diketahui oleh orang lain dan masuk kedalam kategori "Exhibitionist"

Komunikasi yang terjalin antara satu dengan lainnya berjalan dengan baik dan lebih intim. Penyebabnya kebebasan yang sangat besar sehingga dengan leluasanya mereka membagikan hal-hal yang belum pernah mereka bagikan sebelumnya, begitu juga dengan respon dari teman-teman dekatnya yang berada di second account tersebut, mereka saling membalas kesamaan yang mereka rasakan. Semakin besar kesamaan yang mereka rasakan maka semakin besar komunikasi yang dilakukan. Kontribusi penelitian ini berupa rekomendasi kebijakan baru kepada generasi milenial untuk selalu percaya diri dan menjadi diri sendiri.

\section{Daftar Pustaka}

Bazarova, N. N., \& Choi, Y. H. (2014). Selfdisclosure in social media: Extending the functional approach to disclosure motivations and characteristics on social network sites. Journal of Communication, 64(4), 635-657. 
Cangara, Hafied. (1998). Pengantar Ilmu Komunikasi. Jakarta: Raja Grafindo Persada. Cangara, Hafied. (2016). Pengantar Ilmu Komunikasi. Jakarta: Rajawali Pers. Dewi, R., \& Janitra, P. A. (2018). Dramaturgi Dalam Media Sosial: Second Account Di Instagram Sebagai Alter Ego. Jurnal Ilmu Komunikasi, 8(3), 340-347.

DeVito, J. A. (2007). The interpersonal communication (11th ed.). Boston: Pearson Education, Inc. Emeraldien, F. Z., Aulia, A. D., \& Khelsea, Y. O. (2019). The Use of Finstagram as A Platform For Self-Disclosure. Jurnal Ilmu Komunikasi, 2(2), 85-96. Fauzia, A. Z., Maslihah, S., \& Ihsan, H. (2019). Pengaruh Tipe Kepribadian terhadap Self Dsiclosure pada Dewasa Awal Pengguna Media Sosial Instagram di Kota Bandung. Jurnal Psikologi Sains dan Profesi, 3(3), 151-160. https:// doi.org/10.24198/jpsp.v3i3.23434 Ignatius, E., \& Kokkonen, M. (2007). Factors contributing to verbal self-disclosure. Nordic Psychology, 59(4), 362-391. Indriyani, V. R. (2017). Pengungkapan diri siswa di media sosial instagram. Johana, K., Lestari, F. D., \& Fauziah, D. N. (2020). Penggunaan Fitur Instagram Story Sebagai Media Self Disclosure dan Perilaku Keseharian Mahasiswi Public Relations Universitas Mercu Buana. Jurnal Ilmu Manajemen Terapan, 1(3), 280-289. https://doi.org/10.31933/jimt.v1i3.111 Kamilah, F. N., \& Lestari, S. B. (2020). Manajemen Privasi pada Pengguna Media Sosial Instagram. Interaksi Online. 9(1), 98-108. Diakses dari https://ejournal3.undip.ac.id/index.php/ interaksi-online/article/view/29574 Mahardika, R.D.\&Farida.(2019). Pengungkapan Diri pada Instagram Instastory. Jurnal Studi Komunikasi, 3(1), 101-117. http:// dx.doi.org/10.25139/jsk.v3i1.774
Mahendra, B. (2017). Eksistensi Sosial Remaja dalam Instagram (Sebuah Perspektif Komunikasi). Jurnal Visi Komunikasi, 16(1), 151-160. Miranda, D. (2019). Self-Disclosure Mahasiswa Pengguna Instagram Stories (Studi Kasus pada Mahasiswa Ilmu Komunikasi Universitas Muslim Indonesia). Respon Jurnal Ilmiah Ilmu Komunikasi, 1(1). Moleong, Lexy J. (2005). Metodologi Penelitian Kualitatif Edisi Revisi Cet. Ke21. Bandung: PT Remaja Rosdakarya. Ningsih, Widiyana. (2015). Self Disclosure Pada Media Sosial. Banten: Universitas Sultan Ageng Tirtayasa. Prihatiningsih, W. (2017). Motif Penggunaan Media Sosial Instagram di Kalangan Remaja. Communication. 8(1), 51-65. http:// dx.doi.org/10.36080/comm.v8i1.651 Putra, M. R. A. (2019). Kemanfaatan Instagram dalam Pembentukan Citra Diri Remaja Wanita di Makassar. Medialog, 2(1), 1-10. https://doi.org/10.35326/medialog.v2i1.148 Sabaruddin. (2019). Self-Disclosure Pada Mahasiswa Pengguna Instagram. Makassar: Politeknik Pertanian Negeri Pangkep. Sakti, B. C., \& Yulianto, M. (2018). Penggunaan media sosial instagram dalam pembentukan identitas diri remaja. Interaksi Online, 6(4), 490-501. Diakses dari https://ejournal3.undip.ac.id/index. $\mathrm{php} /$ interaksi-online/article/view/21950 Sagiyanto, A., \& Ardiyanti, N. (2018). Self Disclosure Melalui Media Sosial Instagram (Studi Kasus Pada Anggota Galeri Quote). Nyimak: Journal of Communication, 2(1), 81-94. http:// dx.doi.org/10.31000/nyimak.v2i1.687 Setiadi, G. J. (2019). Self Disclosure Individu Androgini melalui Instagram sebagai Media Eksistensi Diri. Jurnal Studi Komunikasi, 3(2), 272-286. http:// dx.doi.org/1 0.25139/jsk.v3i2.1497 
Setiasih, S., \& Puspitasari, F. (2015). The adolescents' needs to post photos and videos in Instagram. Jurnal Psikologi Ulayat: Indonesian Journal of Indigenous Psychology, 2(2), 461-472. https:// doi.org/https://doi.org/10.24854/jpu38

Suyadi, A.A., \& Triyono, A. (2017). Media Sosial dan Self Disclosure (Pengungkapan Diri) (Studi Deskriptif Kualitatif Pengungkapan Diri Terhadap Mahasiswa Ilmu Komunikasi
Universitas Muhammadiyah Surakarta dalam Mengakses Path Berdasarkan Gender). (Doctoral dissertation, Universitas Muhammadiyah Surakarta). Trepte, S. (2015). Social media, privacy, and self-disclosure: The turbulence caused by social media's affordances. Social Media+ Society, 1(1), 2056305115578681. 